Canadian

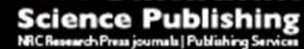

Canadian Journal of Microbiology Revue canadienne de de microbiologie

\title{
Abundance and diversity of ammonia-oxidizing archaea and bacteria in the rhizosphere soil of three plants in the Ebinur Lake wetland
}

\begin{tabular}{|r|l|}
\hline Journal: & Canadian Journal of Microbiology \\
\hline Manuscript ID & cjm-2016-0492.R3 \\
\hline Manuscript Type: & Article \\
\hline Date Submitted by the Author: & 21-Feb-2017 \\
\hline Complete List of Authors: & $\begin{array}{l}\text { He, Yuan; Shihezi University, College of Life Science } \\
\text { Hu, Wenge; Shihezi University, College of Life Science } \\
\text { Ma, Decao; Shihezi University } \\
\text { Lan, Hongzhu; Shihezi University } \\
\text { Yang, Yang; Shihezi University } \\
\text { Gao, Yan; Shihezi University }\end{array}$ \\
\hline Keyword: & $\begin{array}{l}\text { Ammonia-oxidizing bacteria (AOB), Ammonia oxidizing archaea (AOA), q- } \\
\text { PCR, clone library, Rhizosphere soil }\end{array}$ \\
\hline &
\end{tabular}


Abundance and diversity of ammonia-oxidizing archaea and bacteria in the rhizosphere soil of three plants in the Ebinur Lake wetland

Yuan $\mathrm{He}^{1}$, Wenge $\mathrm{Hu}^{*}{ }^{1}$, Decao $\mathrm{Ma}^{1}$, Hongzhu Lan ${ }^{1}$, Yang Yang ${ }^{1}$, Yan Gao ${ }^{1}$

${ }^{1}$ Current Address: College of Life Science, Shihezi University, Shihezi, Xinjiang, China, 832000

Email address for each author:

Yuan He: yuanheedu@163.com

Wenge Hu: wengehushiheziu@163.com

Decao Ma: 15001610086@163.com

Hongzhu Lan: 812030427@qq.com

Yang Yang: 1509371525@qq.com

Yan Gao: 732678157@qq.com

*corresponding author

Name: Wenge Hu

Address: College of Life Science, Shihezi University, Shihezi, Xinjiang, China, 832000

Email: wengehushiheziu@,163.com

Tel: 13519922061 


\section{Abstract}

Ammonia oxidation is carried out by ammonia oxidizing bacteria (AOB) and ammonia oxidizing archaea (AOA). The Ebinur Lake wetland is the best example of a temperate arid zone wetland ecosystem in China. Soil samples were collected from rhizosphere and non-rhizosphere soil containing Halocnemum strobilaceum (H and H'), Phragmites australis (R and R'), and Kareliniacaspia (K and K') to study the relationship between environmental factors and the community structure of AOB and AOA. Phylogenetic analysis showed that the AOA sequences belonged to the Nitrosopumilus and Nitrososphaera clusters. AOB were grouped into Nitrosospira sp. and Nitrosomonas sp. Quantitative polymerase chain reaction (qPCR) results showed that the AOA abundance ranged from $2.09 \times 10^{4}$ to $2.94 \times 10^{5}$ gene copies/g soil. The highest number of AOA was detected in sample $\mathrm{K}$, followed by samples R and H. AOB abundance varied between $2.91 \times 10^{5}$ to $1.05 \times 10^{6}$ gene copies/g soil, which was higher than that of AOA. Redundancy analysis (RDA) indicated that electrical conductivity (EC), $\mathrm{pH}$, and $\mathrm{NH}_{4}{ }^{+}-\mathrm{N}$ might influence the community structure of AOA and AOB. AOB might play a more crucial role in ammonia oxidation based on its higher diversity and abundance compared to AOA in the Ebinur Lake wetland in Xinjiang.

Key words: Ammonia-oxidizing bacteria (AOB); Ammonia oxidizing archaea (AOA); q-PCR; clone library; rhizosphere soil

\section{Introduction}

Ammonia oxidation, the first and rate-limiting step in the nitrification process, is traditionally assumed to be performed mainly by ammonia-oxidizing bacteria (AOB) in a variety of environments [Chen et al. 2014; Gao et al. 2014; Zhang et al. 2015]. AOB commonly belong to the classes $\beta$-proteobacteria and $\gamma$-proteobacteria, and include three primary genera: Nitrosomonas, Nitrosospira, and Nitrosococcus 
[Prosser 2008; Purkhold et al. 2000]. However, this view has changed over time due to the detection of ammonia monooxygenase (AMO) genes in archaea [Könneke et al. 2005], as well as the successful isolation of two autotrophic ammonia-oxidizing archaea (AOA): Nitrosopumilus maritimus from a marine aquarium [Könneke et al. 2005] and Candidatus Nitrosoarchaeum koreensis from agricultural soil [ Jung et al. 2011]. Pester found that the amoA gene sequences of Thaumarchaeota are grouped into the five major clusters: the Nitrosopumilus cluster, the Nitrosotalea cluster, the Nitrososphaera cluster, the Nitrososphaera sister cluster and the Nitrosocaldus cluster [Pester et al. 2012].

By detecting the functional gene amoA, previous studies have investigated the distribution and abundance of AOA and AOB in soil [Ding et al. 2015], sediments [Jin et al. 2011], water columns [Francis et al. 2005], and wastewater [Gao et al. 2014]. A number of studies have demonstrated that AOA typically outnumber AOB by several orders of magnitude in soil environments based on quantitative PCR (qPCR) analysis of amoA genes [Zhang et al. 2015]. However, Sher et al. [2013] found that the number of AOB outnumber AOA in some soil regions, suggesting a possible shift in competitive dominance of ammonia oxidizers under certain conditions. Ebinur Lake wetland national nature reserve is the center of the evolution of oasis and desertification in the northern slope of Tianshan mountains [Ren et al. 2011]. There is high species diversity, but research on species in the Ebinur Lake wetland is still limited. While AOB and AOA play a critical role in the nitrogen $(\mathrm{N})$ biogeochemical cycle, the dominant plants species, Halocnemum strobilaceum, Phragmites australis and Kareliniacaspia, play a key role in regulating the climate and maintaining regional ecological balance in the Ebinur Lake wetland [Liu 2004]. However, studies of AOB in the Ebinur Lake wetland are limited to Chen et al. (2012), Wang et al. (2015), and Hu et al. (2016); these only investigated the diversity and number of AOB and not AOA. 
This study aims to evaluate the diversity and abundance of ammonia-oxidizing microorganisms in three dominant plants using a clone library, quantitative polymerase chain reaction (q-PCR) and redundancy analysis (RDA) to study the relationship between soil environment factors and the diversity and abundance of $\mathrm{AOB}$ and $\mathrm{AOA}$ in the rhizosphere and non-rhizosphere soil of Halocnemum strobilaceum, Phragmites australis, and Kareliniacaspia in the Ebinur Lake wetland. We hope to provide a foundation for future restoration and reconstruction of the wetland ecological environment.

\section{Materials and methods}

\section{Ethics statements}

This research was carried out with the permission of the director (Gao Xiang) and chief (Xu Wei) of the Ebinur Lake wetland bird island station in Xinjiang, where samples were collected.

\section{Site description, sample collection, and physicochemical characteristics analysis}

The Ebinur Lake wetland, which is the center of the lowest depression and salt-water [Ren et al. 2011], is located in northwestern Jinghe County, Xingjiang $\left(82^{\circ} 36^{\prime}-83^{\circ} 50^{\prime} \mathrm{E}, 44^{\circ} 30^{\prime}-45^{\circ} 09^{\prime} \mathrm{N}\right)$, southwest of the Junggar Basin. In this study, three types of plants were chosen: Halocnemum strobilaceum, Phragmites australis, and Kareliniacaspia. Then, three sample plots (sample size: $10 \mathrm{~m} \times 10 \mathrm{~m}$ ) were selected for sampling of each species. In each plot, three plants situated in a triangle were sampled. So, the soil attached to the root in 1-5 cm sphere with monospecies stands of Halocnemum strobilaceum / Phragmites australis / Kareliniacaspia (H / R / K) (totally collected from 9 plants for each vegetation) were mixed and named as rhizosphere soil. Finally, non-rhizosphere soil from Halocnemum strobilaceum / Phragmites australis / Kareliniacaspia (H' / R' / K') was collected from unvegetated areas, where distance from plants was $>5 \mathrm{~m}$. Sampling points for the non-rhizosphere soil and the rhizosphere soil were in the same plot for each species. More detailed descriptions of the sampling sites 
in the Ebinur Lake wetland are listed in Table 1. The soil samples were put into sterile plastic bags and transported to the laboratory on ice. All samples were immediately stored at $-20^{\circ} \mathrm{C}$ after being collected until later use for molecular analysis. Soil physicochemical characteristics were assayed as described by $\mathrm{Lu}$ [1999]. The details of collected samples and their physiochemical parameters are summarized in Table S1.

\section{Table 1 near}

\section{DNA extraction, PCR amplification, clone library construction, and Phylogenetic analyses}

Genomic DNA was extracted from $0.3 \mathrm{~g}$ soil using PowerSoil DNA Isolation Kit (MoBio Company). Archaeal and bacterial $a m o A$ genes were amplified using primers Arch-amoAF / Arch-amoAR and amoA-1F / amoA-2R [Jin et al. 2011]. The PCR products were purified using EasyPure PCR Purification Kit (TransGen Biotech, China) and ligated into pMD18-T vector (Takara, Japan), and the vector primers M13F (-47) / M13R (-48) [Jin et al. 2010] were used to reamplify the cloned DNA fragments. PCR products were screened for correct size and grouped by restricted fragment length polymorphisms (RFLP) with restriction enzymes HaelII and MspI. For each RFLP group, representative clones were selected and sequenced by Beijing Genomics Institute (BGI, Beijing, China). Firstly, operational taxonomic units (OTUs) based on 97\% DNA sequence identity, were calculated using the DOTUR program [Schloss 2005]. Then, nucleotide sequences were aligned using BLASTn. The top-hit amo $A$ gene sequences from were retrieved from GenBank and all sequences were aligned using the Clustal X program [Thompson et al. 1997]. Finally, the phylogenetic tree was constructed using the neighbor-joining technique [Saitou 1987] using Mega 6 software [Tamura 2007] with 1,000 bootstrap replicates.

\section{Quantitative PCR analysis}


AOA and AOB bacteria and archaea population densities were analyzed by qPCR with the LightCycler480 qPCR analyzer using SYBR Green Real-Time PCR Master Mixes (Beijing ComWin Biotech, Beijing, China). In order to set up standard curves, a plasmid carrying the AOA and AOB amoA gene and bacterial and archaeal 16S rDNA fragments was extracted from Escherichia coli hosts and the concentration of plasmid was measured by Thermo NanoDrop 2000 (Thermo, USA). The AOA and $\mathrm{AOB}$ атоA genes were quantified with primer Arch-amoAF/R and amoA-1F/2R. Archaeal and bacterial genes were quantified with primers ARC344F/ARC915R [Nakaya et al. 2009] and 515F/927R [Ducey et al. 2011]. The $10 \mu \mathrm{l}$ qPCR mixture contained the following reagents: $5 \mu \mathrm{L}$ FastStart Universal SYBR Green Master (Rox) (Roche Diagnostics, Mannheim, Germany), $0.2 \mu \mathrm{L}$ of each primer for the amoA gene and the $16 \mathrm{~S}$ rDNA of bacteria and archaea, $1 \mu \mathrm{L}$ plasmid DNA, $3.6 \mu \mathrm{L}$ $\mathrm{ddH}_{2} \mathrm{O}$. The qPCR thermocycling parameters were as follows: an initial denaturation at $95^{\circ} \mathrm{C}$ for $20 \mathrm{~s}$, followed by 35 cycles of denaturing at $95{ }^{\circ} \mathrm{C}$ for $3 \mathrm{~s}$, and annealing at $60{ }^{\circ} \mathrm{C}$ for $30 \mathrm{~s}$. Melting curve analysis was routinely performed to confirm the specificity of the qPCR. In all experiments, negative controls that contained no template DNA were subjected to the same qPCR procedure to detect and exclude any possible contamination or carryover.

\section{Statistical analysis}

The estimated coverage of the amoA gene libraries was calculated using the formula $\mathrm{C}=\left(1-\mathrm{n}_{1} / \mathrm{N}\right)$ $\times 100 \%$, where $\mathrm{C}$ is the homologous coverage, $\mathrm{n}_{1}$ is the number of OTUs containing only one sequence, and $\mathrm{N}$ is the total number of clones that were analyzed in the library [Singleton et al. 2001]. The diversity indices for each sample, including Shannon, Chao1, ACE and Simpson indices, were generated by DOTUR. Correlations between the amo $A$ gene communities and environmental factors were analyzed by the redundancy analysis (RDA) using the software CANOCO for Windows (version 
4.5) [ter Braak 2002].

\section{Nucleotide sequence accession numbers}

The sequences in this study were deposited in GenBank under accession numbers: KX390237KX390476 for AOA, KP126525-KP126604, KP196614-KP196711, KX390477-KX390517 for AOB.

\section{Results}

\section{Diversity and phylogenetic analysis of $\mathrm{AOA}$ and $\mathrm{AOB}$ in the rhizosphere soil}

In this study, library coverage (C) ranged from 98.39 to $100 \%$ (Table 2); this was confirmed by rarefaction analysis (Fig S1a and b). Within each individual sampling site, 2 - 10 AOA OTUs and 8 - 15

AOB OTUs were found. The highest AOA and AOB richness occurred at R, and the lowest occurred in $\mathrm{K}$, which was in accordance with values from the Shannon, Chao1, ACE, and Simpson indices. In addition, AOB showed a higher richness and diversity than AOA in all sample sites.

\section{Table 2 near}

Based on 98, 93, and 49 AOA amo $A$ gene sequences in the $\mathrm{H}, \mathrm{R}$, and $\mathrm{K}$ clone libraries, 7, 10 and 2 OTUs were obtained, respectively. Fig. S2a shows the AOA distribution of OTU relative abundance in the different samples. Among the seven OTUs, H-AOA-OTU4 was the most dominant (60\%). There were 10 OTUs in R, R-AOA-OTU1 (77\%) was dominant; however, there were only 2 OTUs in K, K-AOA-OTU1 (57\%) and K-AOA-OTU2 (43\%), which indicated that the diversity of AOA in K was the lowest, but the highest was in sample R. Figure 1 shows the AOA N-J tree; AOA amoA sequences fell into two clusters: Nitrosopumilus and Nitrososphaera. About $92.92 \%$ of AOA amoA sequences were affiliated to the Nitrosopumilus cluster, which was the largest branch in the phylogenetic tree and was recovered in every sample, whereas the Nitrososphaera cluster accounted for $7.08 \%$. In the K sampling site, all of AOA amoA sequences were affiliated to the Nitrosopumilus cluster. 
Insert Fig. 1 here.

In the $\mathrm{H}, \mathrm{R}$, and $\mathrm{K} \mathrm{AOB}$ clone library, 80, 98, and $41 \mathrm{AOB}$ amo $A$ gene sequences were divided into 9 , 15, and 8 OTUs respectively. This indicated that the diversity of AOB in sample R was highest. Fig. S2b showed that the H-AOB-OTU3 (41.25\%), H-AOB-OTU6 (20\%), R-AOB-OTU10 (18.38\%) and K-AOB-OTU4 (26.83\%) were relatively dominant in H, R and K. The N-J phylogenetic tree (Fig. 2) of AOB based on amoA gene sequences showed that AOB amoA gene OTUs fell into two genera: Nitrosomonas and Nitrosospira. However, only about $9.76 \%$ AOB amoA sequences were affiliated to the Nitrosospira genus, and $90.24 \%$ AOB amoA sequences were assigned to the Nitrosomonas genus, which originated from sample $\mathrm{K}$. All of the $\mathrm{AOB}$ amoA sequences in $\mathrm{H}$ and $\mathrm{R}$ fell into the Nitrosomonas genus, including four clusters: the Nitrosomonas oligotropha cluster, the Nitrosomonas-like cluster, the Nitrosomonas communis cluster and the Nitrosomonas sp. Nm143 cluster. Most of the AOB amoA OTUs in H and R belonged to the $N$. oligotropha cluster (11 OTUs) and the $N$. communis cluster (9 OTUs).

Insert Fig. 2 here

\section{Abundance of the amo $A$ gene, bacterial and archaeal 16S rRNA genes}

Fig. 3 shows qPCR results of AOA and AOB amoA genes, bacterial and archaeal 16S rRNA genes of the six samples, including rhizosphere soil (H, R, K) (Fig. 3a) and non-rhizosphere soil (H', R', K') (Fig. 3b). In this study, the amplification efficiency was greater than $94.3 \%$ for AOA and $93.2 \%$ for $\mathrm{AOB}$ and the error value was less than 0.2. In addition, the melting curve analysis presented a single peak, demonstrating specificity of amplification. The abundance of AOA amoA genes ranged from $2.09 \times 10^{4}$ to $2.94 \times 10^{5}$ copies/g soil, and the highest abundance occurred in sample K, which was almost fourteen fold greater than the lowest (sample H) (Fig. 3a). The abundance of AOB was higher in all 
samples, varying between $2.91 \times 10^{5}$ to $1.05 \times 10^{6}$ copies/g soil. Similar to AOA, the lowest abundance occurred at $\mathrm{H}$, but the highest abundance occurred in sample $\mathrm{R}$. The abundance of AOA and AOB was higher in sample $\mathrm{R}$ than that in non-rhizosphere soil (sample R'), while the abundance of AOA and AOB was lower in sample $\mathrm{H}$ than that in non-rhizosphere soil (sample $\mathrm{H}^{\prime}$ ). In addition, the abundance of AOA was higher in sample $\mathrm{K}$, but the abundance of AOB was higher in sample $\mathrm{K}$ '. In each investigated sample, the ratios of $\mathrm{AOB} / \mathrm{AOA}$ amoA gene copy numbers varied from 2.05 at sample $\mathrm{K}$ to 29.91 at sample R'. Furthermore, the amplification efficiency was greater than $88 \%$ for archaea and $90.5 \%$ for bacteria and the error value was less than 0.1 . In sample $H$, the abundance of both bacteria and archaea were highest, being $4.8 \times 10^{8}$ copies/g soil and $5.15 \times 10^{7}$ copies/g soil, respectively. The abundance of bacteria and archaea were lowest in sample $\mathrm{K}\left(3.51 \times 10^{6}\right.$ copies $\left./ \mathrm{g}\right)$ and sample $\mathrm{K}^{\prime}(8.78$ $\times 10^{5}$ copies/g)

\section{Insert Fig. 3 here}

\section{Relationships of ammonia-oxidizer and environmental factors}

The correlations between AOA and AOB community distributions with environmental parameters were analyzed by RDA. Total N, EC, OM, AP and $\mathrm{NO}_{3}{ }^{-}-\mathrm{N}$ were the main contributors to the diversity and distribution of AOA (Fig. 4a), while AN, total P, total $\mathrm{K}$, and $\mathrm{NH}_{4}{ }^{+}-\mathrm{N}$ were the most important factors influencing the AOB community structure (Fig. 4b). In addition, environmental factors also influenced the abundance of ammonia oxidizers and bacteria and archaea (Fig. 4c). The ratio of AOB/AOA amoA gene copy numbers was correlated positively with $\mathrm{NH}_{4}{ }^{+}-\mathrm{N}$, and negatively with OM. Most of the environmental factors had an influence on the abundance of bacteria and archaea, such as SM, total P, total $\mathrm{K}$, total $\mathrm{N}, \mathrm{AN}, \mathrm{EC}$ and so on.

\section{Insert Fig. 4 here}




\section{Discussion}

This study revealed the presence of both AOA and AOB amoA genes in the Ebinur Lake wetland, which reinforces the idea that the $\mathrm{AOA}$ and $\mathrm{AOB}$ can be found in various natural environments [Francis et al. 2005; Jin et al. 2011; Pester et al. 2012]. Some studies such as those by Herrmann [2008] and Alves [2013], showed that the abundance of AOA outnumbered that of AOB, whereas others studies revealed that AOB communities were more abundant than AOA [Sun et al. 2013; Zheng et al. 2013]. In the present study, AOA and AOB copy numbers varied from $2.09 \times 10^{4}$ to $2.94 \times 10^{5}$ gene copies/g soil and from $2.91 \times 10^{5}$ to $1.05 \times 10^{6}$ gene copies/g soil in the rhizosphere and non-rhizosphere soil of Halocnemum strobilaceum, Phragmites australis and Kareliniacaspia (Fig. 3). These values were three orders of magnitude lower for AOA and one order lower for AOB than those found in rice rhizospheres [Zhang et al. 2016], and two orders of magnitude lower than those found in paddy rhizosphere soil [Chen et al. 2008]. Therefore, this study showed lower abundance of AOA and AOB in the Ebinur Lake wetland, which is related to the saline environment [Ren et al. 2011]. The highest number of AOA was detected in the sample K plot, but the highest diversity of AOA and the highest number and diversity of AOB were detected in sample R. In addition, the abundance of AOA and AOB was higher in sample R than that in sample R', whereas it was lower in sample $H$ than that in sample H'. The abundance of AOA was higher in sample $\mathrm{K}$, but the abundance of AOB was higher in sample $\mathrm{K}$, which indicated that sample $\mathrm{R}$ vegetation had a higher $\mathrm{AOA}$ and $\mathrm{AOB}$ abundance than sample $\mathrm{K}$ or sample $\mathrm{H}$. In sample $\mathrm{K}$, it might be adaptable for $\mathrm{AOA}$ not $\mathrm{AOB}$, the rhizosphere environment of sample $\mathrm{H}$ might be unsuitable for the growth of AOA and AOB, which showed that the abundance and diversity of AOA and $\mathrm{AOB}$ might be related to plant community and plant root secretion, these results showed a good agreement with previous reports [Herrmann et al. 2008, Santoro et al. 2008]. In addition, a large 
number of studies had shown that rhizosphere effects had a strong effect on soil microbial activity, including microbial processes such as nitrogen cycling [Toberman et al. 2011; Concilio et al. 2015]. The positive effect of rhizospheres on nitrification was confirmed in Penton's study [Penton et al. 2013]. However, there are some potential rhizosphere nitrification inhibitors that could slightly inhibit the rhizosphere microbial nitrification activity (Liu et al. 2007). Therefore, some inhibitors or microorganism might have had an influence on the growth of AOA and AOB in the rhizosphere soil of sample H. Furthermore, the abundance and diversity of AOB were higher than those of AOA in all samples, which indicated AOB might dominate the ammonia oxidation progress in the Ebinur Lake wetland, as suggested by Katrin [2010].

Phylogenetic tree analysis showed that AOA amoA sequences from rhizosphere soil fell into two clusters: the Nitrosopumilus (group I.1 a) and Nitrososphaera clusters (group I.1b). In addition, the Nitrosopumilus cluster was distributed in each sample. While most studies found that the Nitrososphaera cluster was the dominant species in soil, the Nitrosopumilus cluster was dominant in the ocean [Massana et al. 2000; Ochsenreiter et al. 2003; Peste et al. 2012]; these results are at odds with the present study. This phenomenon may be related to the salinity level, which fluctuates to a great degree in this area [Qu et al. 2008; Wu et al. 2004], and provides a more suitable environment for the Nitrosopumilus cluster. The Nitrosopumilus cluster was dominant in rhizosphere soil of three plants. Compared to AOA, the AOB amoA gene were grouped into Nitrosospira sp. and Nitrosomonas sp., and Nitrosomonas was the most dominant AOB species. Previous studies about AOB from soil also found similar results [Wang et al. 2015]. Most of the AOB amoA OTUs belonged to the $N$. oligotropha cluster and the $N$. communis cluster, and no AOB sequences belonged to the $N$. europaea cluster, which was consistent with the findings of Kayee [Kayee et al. 2011]. 
The abundance and diversity of AOA and AOB vary in different environments with different environmental factors [Zhang et al. 2015]. In this study, total $\mathrm{N}, \mathrm{EC}, \mathrm{NO}_{3}^{-}-\mathrm{N}, \mathrm{PH}$ and $\mathrm{NH}_{4}^{+}-\mathrm{N}$ were proposed to be the main environmental factors affecting the AOA and AOB. Total $\mathrm{N}$ has been reported to be a potential environmental factor influencing the structure of AOA and AOB communities in the soil [Wessén et al. 2011]. $\mathrm{NH}_{4}{ }^{+}-\mathrm{N}$ and $\mathrm{NO}_{3}{ }^{-}-\mathrm{N}$ might have influence on the diversity and abundance of $\mathrm{AOA}$ and $\mathrm{AOB}$. In recent years, the content of ammonia and nitrogen increased significantly because of the amount of fertilizer and pesticide used on farmland upstream of the Ebinur Lake wetland [Wu et al. 2004]. The higher concentration of ammonia better suited the growth of AOB, and a lower concentration of ammonia was better for suited for AOA growth [Erguder et al. 2009]. Therefore, the abundance and diversity of $\mathrm{AOB}$ was higher than that of AOA. $\mathrm{pH}$ is another important factor for AOA and AOB. Some studies showed that the abundance of AOA in acidic soil was higher than that in alkaline soil [Chen et al. 2011]. The pH in an alkaline sandy loam (pH 7.21 - 8.64) of the Ebinur Lake wetland was not suitable for the growth of AOA. In addition, salinity is a factor that shapes the structure and abundance of ammonia-oxidizing microbial community. Mosier [Mosier et al. 2012] pointed out that the low salinity can enrich AOA, but Zhang Yan [2015] stated that AOA is better equipped than AOB to grow in moderate and high salinity environments. Until now, the effect of salinity on abundance of AOA and AOB remained ambiguous [2015]. In general, higher ammonia concentration, more alkaline soils and high salinity (as well as other environment factors) result in greater abundance and diversity of $\mathrm{AOB}$ as compared to AOA. AOB, not AOA might dominate the ammonia oxidation process in the Ebinur Lake wetland.

\section{Conclusion}

This study provides evidence of the presence of both AOA and AOB in the Ebinur Lake wetland. 
Phylogenetic analysis showed that the AOA amoA sequences fell into Nitrosopumilus and Nitrososphaera clusters; the AOB amoA gene fragments were grouped into Nitrosospira sp. and Nitrosomonas sp. and most of them fell within the Nitrosomonas oligotropha and Nitrosomonas communis clusters. The qPCR results showed that there was a higher abundance of AOA and AOB in sample $\mathrm{R}$ than that in samples $\mathrm{K}$ and $\mathrm{H}$, so the Phragmites australis ( $\mathrm{R}$ ) vegetated terrain might promote the ammonia oxidation to some extent by a plant root secretion in the rhizosphere environment. In sample $\mathrm{H}$, there was a lower $\mathrm{AOA}$ and $\mathrm{AOB}$ abundance than that in sample $\mathrm{H}$ ', showing that the rhizosphere environment of sample $\mathrm{H}$ was not suitable for growth of AOA and AOB; whereas rhizosphere environment of sample $\mathrm{K}$ was suitable for AOA, the non-rhizosphere environment of sample $\mathrm{K}$ was suitable for AOB. Meanwhile, AOB were more abundant than AOA in all investigated samples, suggesting that AOB might play a more significant role in ammonia oxidation. Furthermore, Total $\mathrm{N}, \mathrm{EC}, \mathrm{NO}_{3}{ }^{-}-\mathrm{N}, \mathrm{pH}$, and $\mathrm{NH}_{4}{ }^{+}-\mathrm{N}$ were proposed to be the main environmental factors affecting the community structure and abundance of AOA and AOB in the Ebinur Lake wetland in Xinjiang.

\section{Acknowledgments}

This work was supported by the National Natural Science Foundation of China [grant number 31560040; 31160026]. The authors would like to thank Gao Xiang, Director of the Ebinur Lake wetland National Nature Reserve administration, and Xu Wei, Chief of the Ebinur Lake wetland bird island station in Xinjiang, for having permitted the collection of samples for this study. The authors would like to thank the editor and anonymous reviewers for their valuable comments and suggestions to improve the quality of this paper.

\section{References}

Alves RJ , Wanek W, Zappe A, Richer A, Svenning MM, Schleper C, et al. 2013. Nitrification rates in 
Arctic soils are associated with functionally distinct populations of ammonia-oxidizing archaea. ISME J 7(8): 1620-1631

Chen DW, Wang XG, Hu WG, Yang D, Lu LP, Dong YY. 2012. Correlation analysis between the distribution of ammonia-oxidizing bacteria and soil environment in Ebinur Lake Wetland Microbiology China 39(3): 334-343

Chen X, Zhang LM, Shen JP, Wei WX, He JZ. 2011. Abundance and community structure of ammonia-oxidizing archaea and bacteria in an acid paddy soil. Biol Fert Soils 47(3): 323-331.

Chen XP, Zhu YG, Xia Y, Shen JP, He JZ. 2008. Ammonia-oxidizing archaea: important players in paddy rhizosphere soil? Environ Microbiol 10(8): 1978-1987.

Chen Y, Zhen Y, He H, Lu X, Mi T, Yu Z. 2014. Diversity, abundance, and spatial distribution of ammonia-oxidizing beta-proteobacteria in sediments from Changjiang Estuary and its adjacent area in East China Sea. Microb Ecol 67(4): 788-803

Concilio A, Vargas T, Cheng W. 2015. Rhizosphere-mediated effects of the invasive grass Bromus tectorum L. and native Elymus elymoides on nitrogen cycling in Great Basin Desert soils. Plant and Soil 393(1): 245-257

Ding K, Wen X, Li Y, Shen B, Zhang B. 2015. Ammonia-oxidizing archaea versus bacteria in two soil aquifer treatment systems. Appl Microbiol Biotechnol 99(3): 1337-47

Ducey TF, Shriner AD, Hunt PG. 2011. Nitrification and denitrification gene abundances in swine sastewater anaerobic lagoons. J Environ Qual 40(2): 610-619

Erguder T H, Boon N, Wittebolle L, Marzorati M, Verstraete W. 2009. Environmental factors shaping the ecological niches of ammonia-oxidizing archaea. FEMS Microbiol Rev 33(5): 855-869

Francis CA, Roberts KJ, Beman JM, Santoro AE, Oakley BB. 2005. Ubiquity and diversity of 
ammonia-oxidizing archaea in water columns and sediments of the ocean. Proc Natl Acad Sci USA 102(41): 14683-14688.

Gao J, Luo X, Wu G, Li T, Peng Y. 2014. Abundance and diversity based on amoA genes of ammonia-oxidizing archaea and bacteria in ten wastewater treatment systems. Appl Microbiol Biotechnol 98(7): 3339-3354

Herrmann M, Saunders AM, Schramm A. 2008. Archaea dominate the ammonia-oxidizing community in the rhizosphere of the freshwater macrophyte Littorella uniflora. Appl Environ Microbiol 74(10): $3279-3283$

Hu WG, He Y, Chen DW, Mo C, Guo Y, Ma DC. 2016. Diversity of ammonia-oxidizing bacteria in relation to soil environment in Ebinur Lake Wetland. Biotechnology \& Biotechnological Equipment 30(2): $1-9$

Jin T, Zhang T, Yan Q. 2010. Characterization and quantification of ammonia-oxidizing archaea (AOA) and bacteria $(\mathrm{AOB})$ in a nitrogen-removing reactor using T-RFLP and qPCR. Appl Microbiol Biotechnol 87(3): 1167-1176

Jin T, Zhang T, Ye L, Lee OO, Wong YH, Qian PY.. 2011. Diversity and quantity of ammonia-oxidizing Archaea and Bacteria in sediment of the Pearl River Estuary, China. Appl Microbiol Biotechnol 90(3): $1137-1145$

Jung MY, Park SJ, Min D, Kim JS, Rijpstra WI, Sinninghe Damste JS, et al. 2011. Enrichment and characterization of an autotrophic ammonia-oxidizing archaeon of mesophilic crenarchaeal group I.1a from an agricultural soil. Appl Environ Microbiol 77(24): 8635-8647 
Katrin G, Evelyn H, Erich I, Joseph S, Wolfgang W, Sophie ZB, et al. 2010. Dynamics of ammonia-oxidizing communities in barley-planted bulk soil and rhizosphere following nitrate and ammonium fertilizer amendment. FEMS Microbiol Ecol 74(3): 575-591

Kayee P, Sonthiphand P, Rongsayamanont C, Limpiyakorn T. 2011. Archaeal amoA genes outnumber bacterial amoA genes in municipal wastewater treatment plants in Bangkok. Microb Ecol 62(4): 776-788

Könneke M, Bernhard AE, de la Torre JR, Walker CB, Waterbury JB, Stahl DA. 2005. Isolation of an autotrophic ammonia-oxidizing marine archaeon. Nature 437(7058): 543-546

Liu R, Hayden H, Suter H, He J, Chen D. 2015. The effect of nitrification inhibitors in reducing nitrification and the ammonia oxidizer population in three contrasting soils. Journal of Soils and Sediments 15(5): 1113-1118

Liu Y. 2004. Protect wetland and improve eco-environment of Ebinur Wetland Lake. Environmental Science Trend 4:3-5.

Lu RK. 1999. Chemical Analysis Methods Of Soil Agriculture. Agriculture Science and technology, China

Massana R, DeLong EF, Pedros-Alio C. 2000. A few cosmopolitan phylotypes dominate planktonic archaeal assemblages in widely different oceanic provinces. Appl Environ Microbiol 66(5): 1777-1787

Mosier AC, Lund MB, Francis CA. 2012. Ecophysiology of anammonia-oxidizing archaeon adapted to low-salinity habitats. Microb Ecol 64(4): 955-963.

Nakaya A, Onodera Y, Nakagawa T, Satoh K, Takahashi R, Sasaki S, et al. 2009. Analysis of ammonia monooxygenase and archaeal 16S rRNA gene fragments in nitrifying acid-sulfate soil microcosms. Microbes Envir 24(2):168-174

Ochsenreiter T, Selezi D, Quaiser A, Bonch-Osmolovskaya L, Schleper C. 2003. Diversity and abundance of Crenarchaeota in terrestrial habitats studied by 16S RNA surveys and real time PCR. 16 
Environ Microbiol 5(9):787-797

Penton CR, Deeknik J, Popp B, Bruland G, Tiedje JM, Engstrom P, et al. 2013. Importance of sub-surface rhizosphere-mediated coupled nitrification-denitrification in a flooded agroecosystem in Hawaii. Soil Biology \& Biochemistry 57(57): 362-373.

Pester M, Rattei T, Flechl S, Grogroft A, Richter A, Overmann J, et al. 2012. amoA-based consensus phylogeny of ammonia-oxidizing archaea and deep sequencing of amo $A$ genes from soils of four different geographic regions. Environ Microbiol 14(2): 525-539

Prosser JI, Nicol GW. 2008. Relative contributions of archaea and bacteria to aerobic ammonia oxidation in the environment. Environ Microbiol 10(11): 2931-41.

Purkhold U, Pommerening-Roser A, Juretschko S, Schmid MC, Koops HP, Wagner M. 2000. Phylogeny of all recognized species of ammonia oxidizers based on comparative 16S rRNA and amo $\mathrm{A}$ sequence analysis: Implications for molecular diversity surveys. Appl Environ Microbiol 66(12): $5368-5382$.

Qu XX, Huang ZY, Baskin JM, Baskin CC. 2008. Effect of temperature, light and salinity on seed germination and radicle growth of the geographically widespread halophyte shrub Halocnemum strobilaceum Ann Bot 101(2): 293-299

Ren JL, Jin HL, Ye M, Jin WG, Man ZL. 2011. Analysis and evaluation of water quality of Aibihu Lake Wetland Natural Reserve. Journal of Arid Land Resources and Environment 25(5):154-157

Saitou N, Nei M. 1987. The Neighbor-joining method: A new method for reconstructing phylogenetic trees. Mol Biol Evol 4(4):406-425

Santoro AE, Francis CA, de Sieyes NR, Boehnm AB. 2008. Shifts in the relative abundance of ammonia-oxidizing bacteria and archaea across physicochemical gradients in a subterranean estuary. 
Environ Microbiol 10(4): 1068-1079

Schloss PD, Handelsman J. 2005. Introducing DOTUR, a computer program for defining operational taxonomic units and estimating species richness. Appl Environ Microbiol 71(3):1501-1506

Sher Y, Zaady E, Nejidat A. 2013. Spatial and temporal diversity and abundance of ammonia oxidizers in semi-arid and arid soils: indications for a differential seasonal effect on archaeal and bacterial ammonia oxidizers. FEMS Microbiol Ecol 86(3): 544-556

Singleton DR, Furlong MA, Rathbun SL, Whitman WB. 2001. Quantitative Comparisons of 16S rRNA Gene Sequence Libraries from Environmental Samples. Appl Microbiol Biotechnol 67(9): 4374-4376.

Sun W, Xia C, Xu M, et al .2013. Distribution and abundance of archaeal and bacterial ammonia oxidizers in the sediments of the Dongjiang River, a drinking water supply for Hong Kong. Microbes Environ 28(4): 457-465

Tamura K, Dudley J, Nei M, Kumar S. 2007. MEGA4: Molecular Evolutionary Genetics Analysis (MEGA) software version 4.0. Mol Biol Evol 24(8): 1596-1599

ter Braak CJF, Šmilauer P. 2002. CANOCO reference manual and CanoDraw for Windows user's guide: software for Canonical Community Ordination (version 4.5). Ithaca: Microcomputer Power

Thompson JD, Gibson TJ, Plewniak F, Jeanmougin F, Higgins DG. 1997. The CLUSTAL_X windows interface: flexible strategies for multiple sequence alignment aided by quality analysis tools. Nuclei Acids Res 25(24): 4876-4882

Toberman, Hannah. 2011. Rhizosphere effects on soil nutrient dynamics and microbial activity in an Australian tropical lowland rainforest. Soil Research, 49(7): 652-660

Wang CH, Wu F, Hu WG, Mo C, Zhang XH. 2015. Community diversity of ammonia-oxidizing bacteria of three plants rhizosphere in Ebinur Lake wetland. Acta Microbiologica Sinica 55(9): 
$1190-1200$

Wessén E, Söderström M, Stenberg M, Bru D, Hellman M, Welsh A, et al. 2011. Spatial distribution of ammonia-oxidizing bacteria and archaea across a 44-hectare farm related to ecosystem functioning.

ISME J 5(7): 1213-1225

Wu JL, Liu JJ, Wang SM. 2004. Climatic change record from stable isotopes in Lake AIBI, Xinjiang during the past 1500 years. Quaternary Sciences 24(5): 585-589.

Zhang J, Dai Y, Wang Y, Wu Z, Xie S, Liu Y. 2015. Distribution of ammonia-oxidizing archaea and bacteria in plateau soils across different land use types. Appl Microbiol Biotechnol 99(16):6899-6909

Zhang JP, Zhou XH, Chen Lei, Chen ZG, Chu JY, Li YM. 2016. Comparison of the abundance and community structure of ammonia oxidizing prokaryotes in rice rhizosphere under three different irrigation cultivation modes. World J Microbiol Biotechnol 32(5): 1-15

Zhang Y, Chen LJ, Dai TJ, Tian JP, Wen DH. 2015. The influence of salinity on the abundance, transcriptional activity, and diversity of AOA and AOB in an estuarine sediment:a microcosm study. Appl Microbiol Biotechnol 99(22): 9825-9833

Zheng Y L, Hou L J, Liu M et al. 2013. Diversity, abundance, and activity of ammonia-oxidizing bacteria and archaea in Chong ming eastern intertidal sediments. Appl Microbiol Biotechnol 97(18): $8351-8363$

\section{Figure legends:}

Fig. 1 Neighbor-joining phylogenetic tree based on AOA amoA gene sequences

Note: every number behind of OTU represents the number of OTU, and every bracket's number represents the number of sequence in this OTU. $\mathbf{\Delta}$ : AOA clone library of Halocnemum strobilaceum rhizosphere soil, $\bullet$ : AOA clone library of Phragmites australis rhizosphere soil, $\mathbf{m}$ : AOA clone library of 
Kareliniacaspia rhizosphere soil. AOA: ammonia oxidizing archaea

Fig. 2 Neighbor-joining phylogenetic tree based on AOB amoA gene sequences

Note: every number behind of OTU represents the number of OTU, and every bracket's number represents the number of sequence in this OTU. $\mathbf{\Delta}$ : AOB clone library of Halocnemum strobilaceum rhizosphere soil, $\bullet$ : AOB clone library of Phragmites australis rhizosphere soil, $\mathbf{m}:$ AOB clone library of Kareliniacaspia rhizosphere soil. AOB: ammonia-oxidizing bacteria

Fig. 3 Abundance of the amoA gene, bacterial and archaeal 16S rRNA genes in the rhizosphere (a) and non-rhizosphere (b) soil

Note: H, Halocnemum strobilaceum rhizosphere soil; R, Phragmites australis rhizosphere soil; K, Kareliniacaspia rhizosphere soil. H', Halocnemum strobilaceum non-rhizosphere soil; R', Phragmites australis non-rhizosphere soil; K', Kareliniacaspia non-rhizosphere soil.

Fig. 4 Redundancy analysis (RDA) ordination plots for the environmental factors and community composition( $\mathrm{a}$ and $\mathrm{b}$ ) and abundance (c) of AOA and AOB

Note: H, Halocnemum strobilaceum rhizosphere soil; R, Phragmites australis rhizosphere soil; K, Kareliniacaspia rhizosphere soil. H', Halocnemum strobilaceum non-rhizosphere soil; R', Phragmites australis non-rhizosphere soil; K', Kareliniacaspia non-rhizosphere soil.

\section{Supplementary data}

Fig. S1 Rarefaction curves of amoA gene sequences from three rhizosphere soils in Ebinur Lake wetland

Note: H, Halocnemum strobilaceum rhizosphere soil; R, Phragmites australis rhizosphere soil; K, Kareliniacaspia rhizosphere soil. AOA: ammonia oxidizing archaea; AOB: ammonia-oxidizing 
bacteria.

Fig. S2 Distribution and relative abundance of AOA (a) and AOB (b) amoA gene OTUs in three rhizosphere soils in the Ebinur Lake wetland.

Note: H, Halocnemum strobilaceum rhizosphere soil; R, Phragmites australis rhizosphere soil; K, Kareliniacaspia rhizosphere soil. AOA: ammonia oxidizing archaea; AOB: ammonia-oxidizing bacteria. 
Table 1 Basic description of sampling sites in the Ebinur Lake Wetland

\begin{tabular}{cccccc}
\hline Site & Longitude & Latitude & Elevation $(\mathrm{m})$ & Vegetation types & Soil types \\
\hline $\mathrm{H}^{\prime} \mathrm{H}^{\prime}$ & $82^{\circ} 48^{\prime} 49.8^{\prime \prime} \mathrm{E}$ & $44^{\circ} 50^{\prime} 51.6^{\prime \prime} \mathrm{N}$ & 186 & $\begin{array}{c}\text { Halocnemum } \\
\text { strobilaceum }\end{array}$ & $\begin{array}{c}\text { Clay, Sandy } \\
\text { loam soil }\end{array}$ \\
$\mathrm{R} / \mathrm{R}^{\prime}$ & $82^{\circ} 49^{\prime} 50.0^{\prime \prime} \mathrm{E}$ & $4^{\circ} 49^{\prime} 58.7^{\prime \prime} \mathrm{N}$ & 189 & $\begin{array}{c}\text { Phragmites } \\
\text { australis }\end{array}$ & $\begin{array}{c}\text { Clay, Sandy } \\
\text { loam soil }\end{array}$ \\
$\mathrm{K} / \mathrm{K}^{\prime}$ & $82^{\circ} 52^{\prime} 11.37^{\prime \prime} \mathrm{E}$ & $44^{\circ} 44^{\prime} 6.792^{\prime \prime} \mathrm{N}$ & 184 & Kareliniacaspia & Sandy loam \\
& & & & & soil \\
\hline
\end{tabular}

H/H' = Rhizosphere/Non-rhizosphere soil of Halocnemum strobilaceum; R/R'= Rhizosphere/ Non-rhizosphere soil of Phragmites australis; K/K'= Rhizosphere/Non-rhizosphere soil of Kareliniacaspia 
Table 2 Diversity characteristics of AOA and AOB clone library in rhizosphere of Halocnemum strobilaceum, Phragmites australis and Kareliniacaspia

\begin{tabular}{ccccccccc}
\hline Sample & $\begin{array}{c}\text { Clone } \\
\text { number }\end{array}$ & $\begin{array}{c}\text { Sequences } \\
\text { number }\end{array}$ & OTU $_{\mathrm{S}}$ & $\begin{array}{c}\text { Shannon- } \\
\text { Wiener index }\end{array}$ & $\begin{array}{c}\text { Ace } \\
\text { index }\end{array}$ & $\begin{array}{c}\text { Simpson } \\
\text { index }\end{array}$ & $\begin{array}{c}\text { Chaol } \\
(\%)\end{array}$ \\
\hline AOA & & & & & & & & \\
H & 307 & 98 & 7 & 1.08 & 7.79 & 0.53 & 7 & $99.67 \%$ \\
$\mathrm{R}$ & 311 & 93 & 10 & 1.13 & 16.02 & 0.63 & 15 & $98.39 \%$ \\
$\mathrm{~K}$ & 165 & 49 & 2 & 0.68 & 0 & 0.5 & 2 & $100 \%$ \\
$\mathrm{AOB}$ & & & & & & & & \\
$\mathrm{H}$ & 270 & 80 & 9 & 1.93 & 9.99 & 0.23 & 10 & $99.26 \%$ \\
$\mathrm{R}$ & 281 & 98 & 15 & 2.44 & 16.43 & 0.26 & 16.5 & $98.93 \%$ \\
$\mathrm{~K}$ & 280 & 41 & 8 & 1.91 & 8 & 0.13 & 8 & $100 \%$ \\
\hline
\end{tabular}

H: Rhizosphere soil of Halocnemum strobilaceum; R: Rhizosphere soil of Phragmites australis; K: Rhizosphere soil of Kareliniacaspia 


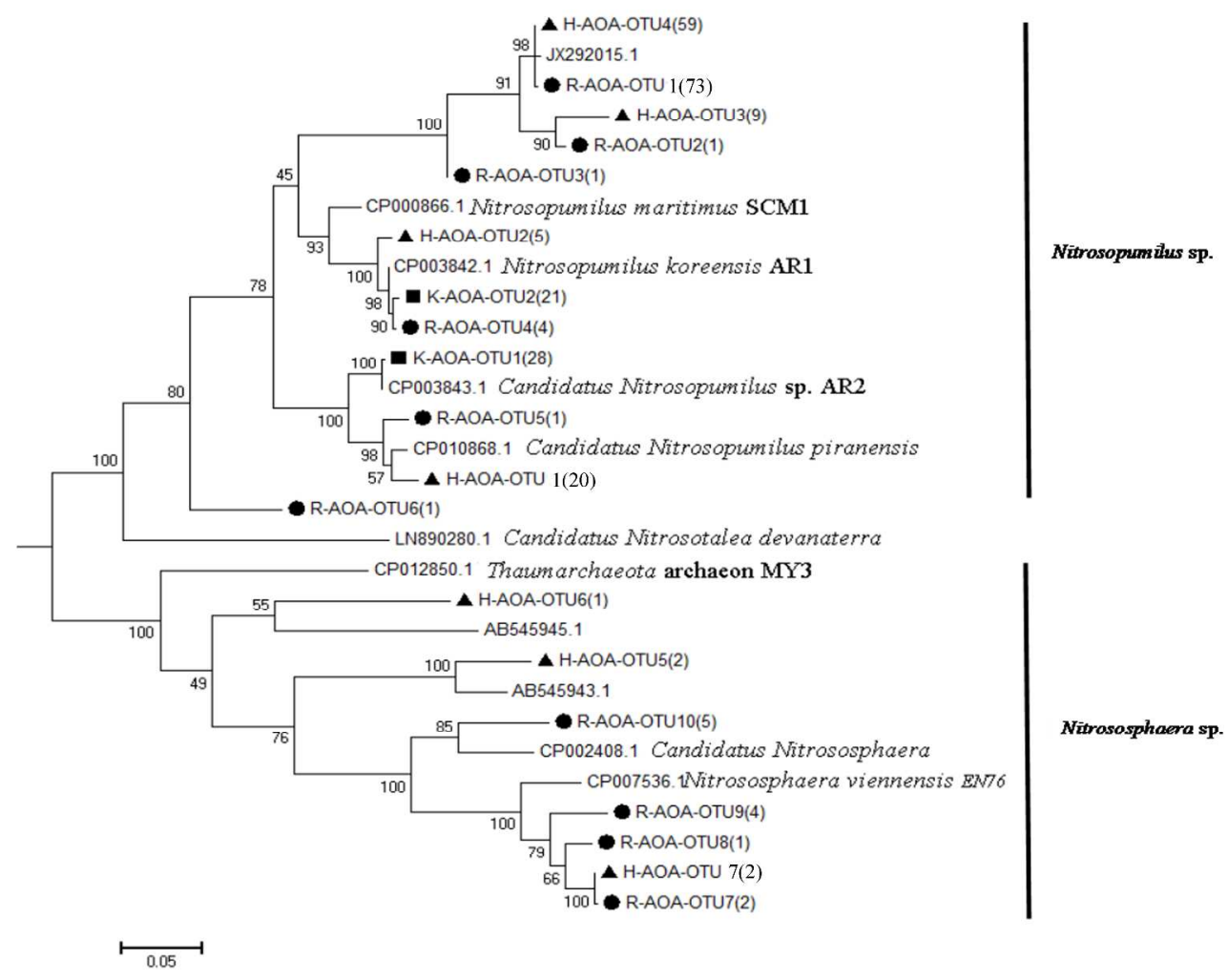

$383 \times 301 \mathrm{~mm}(300 \times 300 \mathrm{DPI})$ 


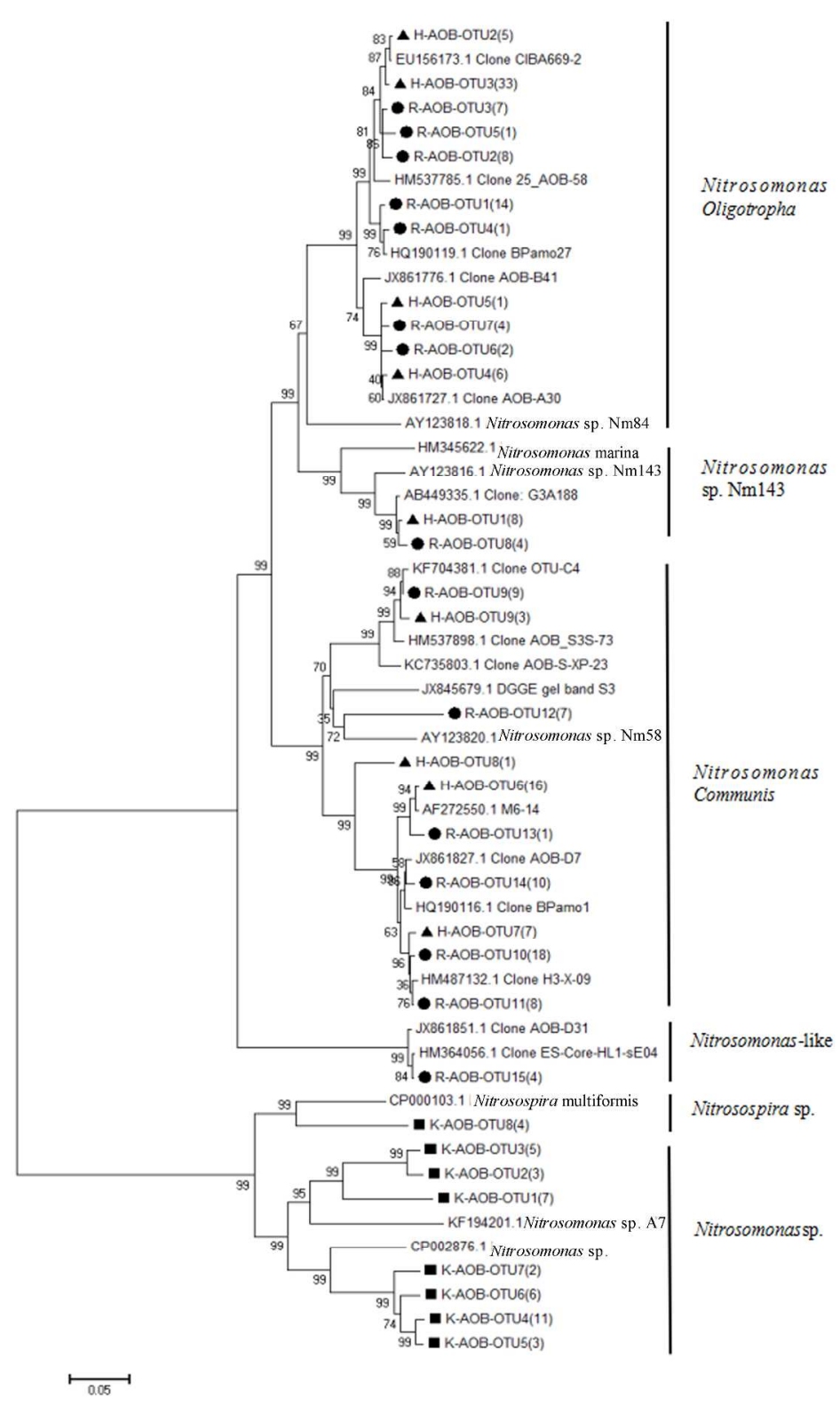

$217 \times 356 \mathrm{~mm}(300 \times 300 \mathrm{DPI})$ 

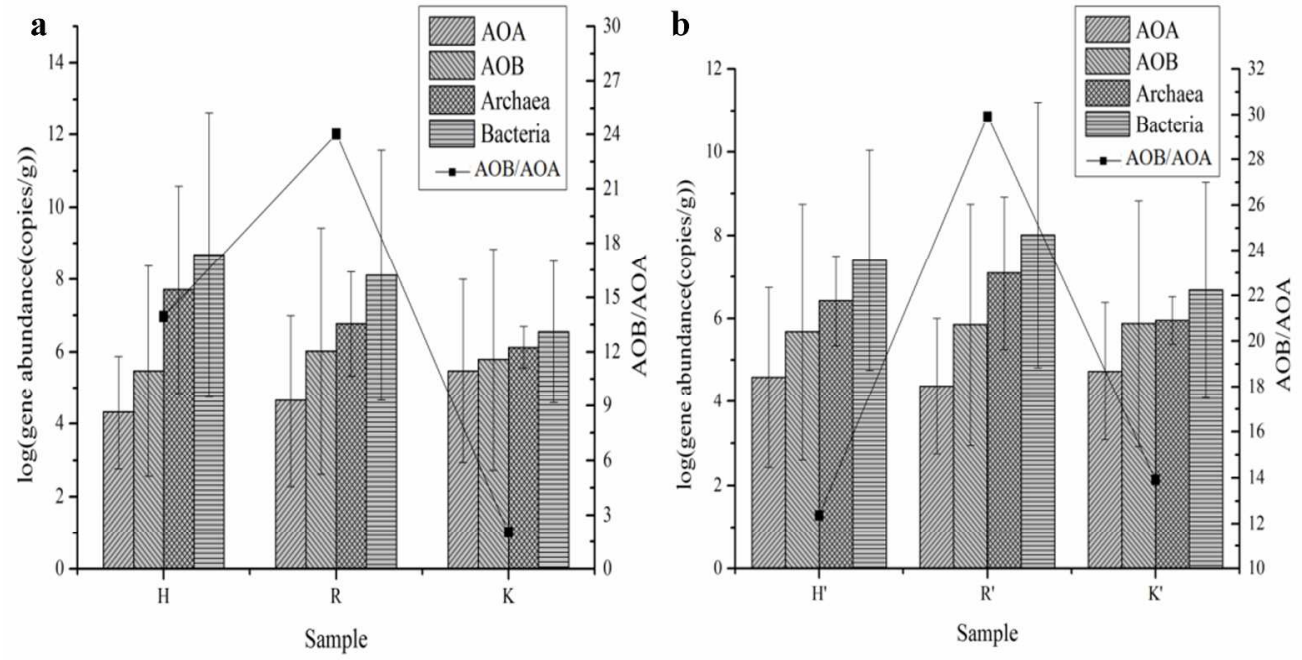

$378 \times 197 \mathrm{~mm}(300 \times 300$ DPI $)$ 

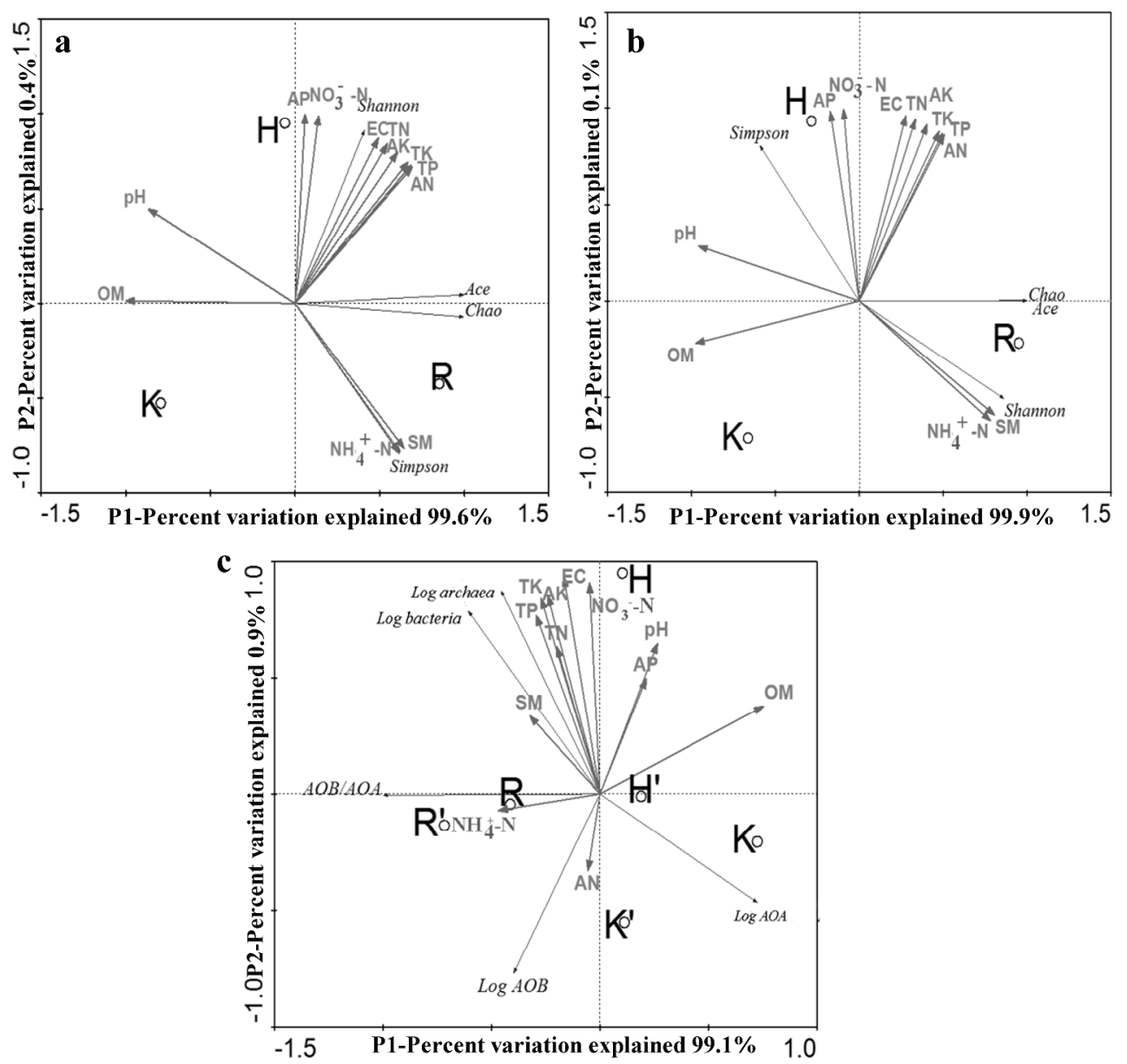

$404 \times 382 \mathrm{~mm}(300 \times 300$ DPI $)$ 
Table S1 The result of physical and chemical properties

\begin{tabular}{|c|c|c|c|c|c|c|c|c|c|c|c|c|}
\hline \multirow{2}{*}{$\begin{array}{c}\text { Sample } \\
\text { plot }\end{array}$} & \multicolumn{12}{|c|}{ Soil physiochemical factors } \\
\hline & $\mathrm{pH}$ & $\mathrm{SM}(\%)$ & $\mathrm{EC}(\mathrm{ms} / \mathrm{cm})$ & $\mathrm{OM}(\mathrm{g} / \mathrm{kg})$ & $\mathrm{TN}(\mathrm{g} / \mathrm{kg})$ & $\mathrm{AN}(\mathrm{mg} / \mathrm{kg})$ & $\mathrm{NH}_{4}^{+}-\mathrm{N}(\mathrm{mg} / \mathrm{kg})$ & $\mathrm{NO}_{3}^{-}-\mathrm{N}(\mathrm{mg} / \mathrm{kg})$ & $\mathrm{TP}(\mathrm{g} / \mathrm{kg})$ & $\mathrm{AP}(\mathrm{mg} / \mathrm{kg})$ & $\mathrm{TK}(\mathrm{g} / \mathrm{kg})$ & $\mathrm{AK}(\mathrm{mg} / \mathrm{kg})$ \\
\hline $\mathrm{H}$ & 8.64 & 14.39 & 10.65 & 5.06 & 0.72 & 33.63 & 7.33 & 3.11 & 0.88 & 32.23 & 6.51 & 296.95 \\
\hline $\mathrm{H}^{\prime}$ & 8.56 & 17.60 & 5.21 & 4.05 & 0.65 & 29.51 & 6.52 & 0.92 & 0.61 & 29.06 & 5.90 & 279.38 \\
\hline $\mathrm{R}$ & 8.20 & 18.64 & 7.38 & 3.57 & 0.56 & 30.20 & 9.13 & 1.59 & 0.83 & 25.85 & 6.12 & 281.14 \\
\hline $\mathrm{R}^{\prime}$ & 8.11 & 20.25 & 4.26 & 3.39 & 0.46 & 27.45 & 8.42 & 1.28 & 0.70 & 25.01 & 5.47 & 263.57 \\
\hline $\mathrm{K}$ & 8.61 & 16.09 & 3.42 & 6.20 & 0.32 & 18.53 & 8.11 & 1.18 & 0.67 & 24.87 & 5.01 & 249.51 \\
\hline $\mathrm{K}^{\prime}$ & 7.21 & 1.38 & 2.18 & 3.15 & 0.54 & 65.78 & 6.96 & 1.12 & 0.62 & 30.32 & 4.36 & 228.76 \\
\hline
\end{tabular}

$\mathrm{H}=\mathrm{Rhizosphere}$ of Halocnemum strobilaceum, $\mathrm{H}^{\prime}=$ Non-rhizosphere of Halocnemum strobilaceum, $\mathrm{R}=\mathrm{Rhizosphere} \mathrm{of} \mathrm{Phragmites} \mathrm{australis,} \mathrm{R}$ '= Non-rhizosphere of Phragmites australis, K= Rhizosphere of Kareliniacaspia Less, K'= Non-rhizosphere of Kareliniacaspia Less. pH pH, SM soil moisture, EC electrical conductivity, $O M$ organic matter, $T N$ total Nitrogen, $A N$ available Nitrogen, $T P$ total Phosphorus, $A P$ available Phosphorus $\mathrm{P}, T K$ total Potassium, $A K$ available Potassium, $N H_{4}{ }^{+}-N$ ammonium content, $\mathrm{NO}_{3}{ }^{-} \mathrm{N}$ nitric nitroge 

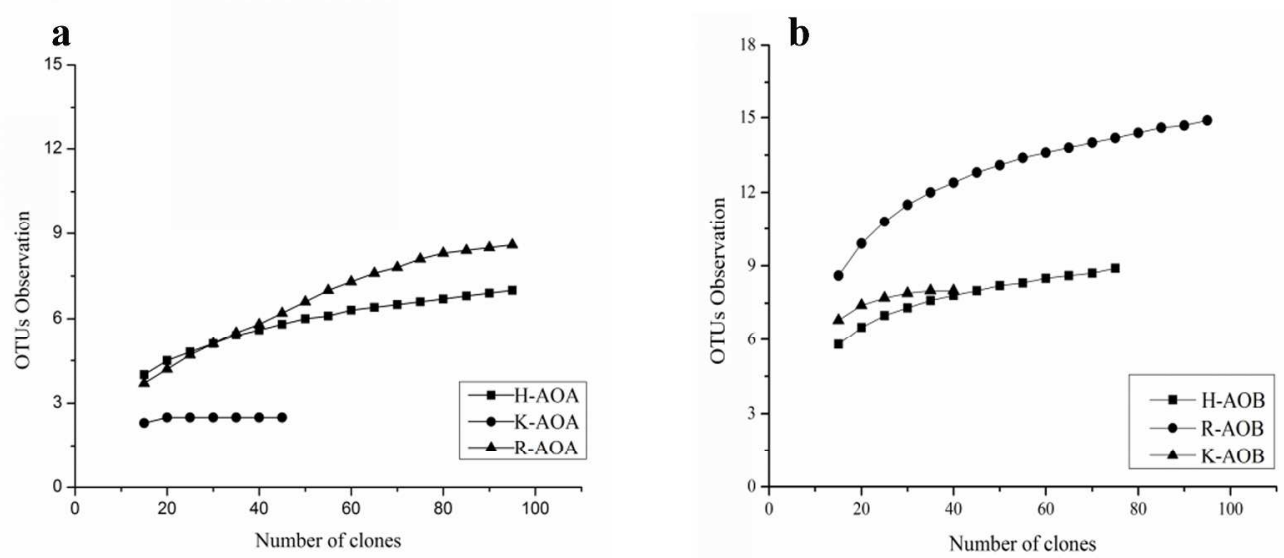

$390 \times 171 \mathrm{~mm}(300 \times 300$ DPI $)$ 


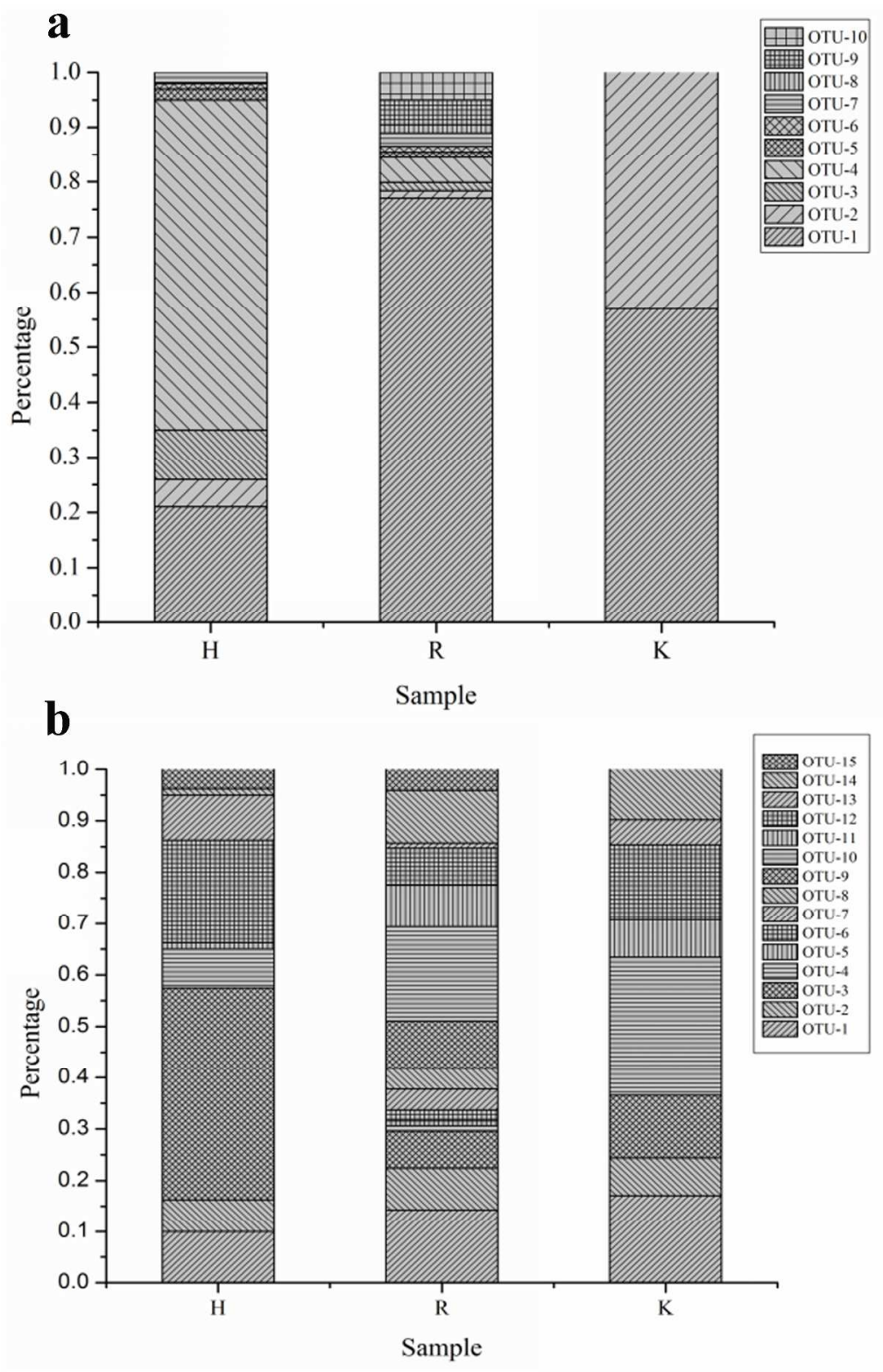

$220 \times 340 \mathrm{~mm}(300 \times 300$ DPI $)$ 